\title{
Simple and green synthesis of calcium alginate/AgCl nanocomposites with low-smoke flame-retardant and antimicrobial properties
}

\author{
Xin Zhang • Qing Zhang $\cdot$ Yun Xue $\cdot$ Yanwei Wang $\cdot$ Xiaodong Zhou • \\ Zichao Li $\cdot$ Qun Li
}

Received: 5 November 2020/Accepted: 9 March 2021 / Published online: 22 March 2021

(C) The Author(s), under exclusive licence to Springer Nature B.V. 2021

\begin{abstract}
Fire hazards and infectious diseases result in great threats to public safety and human health, thus developing multi-functional materials to deal with these issues is critical and yet has remained challenging to date. In this work, we report a facile and ecofriendly synthetic approach for the preparation of calcium alginate/silver chloride $(\mathrm{CA} / \mathrm{AgCl})$ nanocomposites with dual functions of excellent flame-retardant and antibacterial activity. Multi characterization techniques and antibacterial assays were performed to investigate the flame-retardant and antibacterial properties of the $\mathrm{CA} / \mathrm{AgCl}$ nanocomposites. The obtained results show that the $\mathrm{CA} / \mathrm{AgCl}$ nanocomposites exhibited much higher limiting oxygen index value $(>60 \%)$ than that of CA (48\%) with a UL-94 rating of $\mathrm{V}-0$. Moreover, $\mathrm{CA} / \mathrm{AgCl}$ particularly displayed an efficiently smoke-suppressive feature by achieving a total smoke release value of $2.7 \mathrm{~m}^{2} / \mathrm{m}^{2}$, which was reduced by $91 \%$, compared to $\mathrm{CA}$. The antibacterial
\end{abstract}

X. Zhang · Q. Zhang · Y. Xue · Y. Wang ·

X. Zhou · Q. Li (ه)

College of Chemistry and Chemical Engineering, Shandong Collaborative Innovation Center of Marine Biobased Fibers and Ecological Textiles, Qingdao University, Qingdao 266071, China

e-mail: qunli@qdu.edu.cn

\section{Z. Li ( $\square)$}

Institute of Biomedical Engineering, College of Life Sciences, State Key Laboratory of Bio-Fibers and EcoTextiles, Qingdao University, Qingdao 266071, China e-mail: zichaoli@qdu.edu.cn rates of the $\mathrm{CA} / \mathrm{AgCl}$ nanocomposites against E. coli and $\mathrm{S}$. aureus were measured to be $99.67 \%$ and $99.77 \%$, respectively, while CA showed quite weak antibacterial rates. In addition, the flame-retardant and antibacterial mechanisms were analyzed and proposed based on the experimental data. This study provides a novel nanocomposite material with both flame-retardant and antibacterial properties which show promising application prospects in the fields of decorative materials and textile industry.

Keywords Alginate polysaccharides $\cdot \mathrm{AgCl}$. Flame-retardant $\cdot$ Pyrolysis $\cdot$ Antibacterial mechanism

\section{Introduction}

Fire is one of the most permanent and serious disasters that endangers human society. The smoke from fire can hinder the extinguishing of fire and affect the escape of people, which has been the main cause of the suffocation and casualties. Hence, it has always been critical to design materials with reliable flame-retardant and smoke emission-suppressive properties. Meanwhile, it also arouses major concern as public places are usually the main transmission medium for many infectious diseases including hepatitis, influenza, dysentery, trachoma, tinea pedis, novel coronavirus pneumonia and others [1]. Therefore, it is 
desirable to achieve high-performance flame-retardant materials with antibacterial function when applied in public places such as the transportation, theaters, shopping mall, in order to overcome the problem of the harm of fires and infectious diseases simultaneously.

Alginate, constituted of $\beta$-D-mannuronic acid (M block) and $\alpha$-L-guluronic acid ( $\mathrm{G}$ block), is a polysaccharide with abundant natural reserves (Das et al. 2017; Liu et al. 2016c; Luo et al. 2015). As a renewable biomass, it is preferable for its intrinsic features including non-toxic, well degradability and biocompatibility (Das et al. 2017; Googerdchian et al. 2012; Lee and Mooney 2012), and thus it has attracted great interest in recent years ( $\mathrm{Li}$ et al. 2017a, b; Liu et al. 2015a; Senturk Parreidt et al. 2018). Based on these reports, calcium alginate (CA) has been proved to be a desirable material for applications in the textile industry (Agnieszka Kyzioł; Mokhena and Luyt 2017a) due to its inert nature and good flame retardant property, although its mechanism still needs to be clarified (Shao et al. 2019; Wang et al. 2015). Noticeably, the studies have shown that the limiting oxygen index (LOI) value of CA was around 34, which is limited as a desirable flame-retardant agent. Moreover, CA itself has not been verified as a multifunctional material, for instance, it exhibited almost no antibacterial activity. In this aspect, it is essential to improve the flame retardancy of CA for practical application, and meanwhile to gain more functions to broaden its utilization.

Composite materials enable various components to complement each other in performance and produce the synergistic effects through the interaction of two phases, so that the comprehensive performance of composite materials could be better than that of the original constituent materials to meet different demands (Lee et al. 2015; Li et al. 2015). Our previous studies indicate that alginate is a suitable biological matrix to synthesize functional nanocomposites with the advantages of both resource conservation and environmental protection (Liu et al. 2018b; Xu et al. 2019). The alginate grid not only displayed the ability to guide the growth of inorganic nanoparticles (NPs), but also prevented the formed NPs from aggregation and acted as a stabilizer as well (Kou and Varma 2012). Moreover, in terms of native alginate, the synthesis of alginate-NP based composites has been proved to be an efficient approach to improve the flame retardancy (Liu et al. 2018a; Xu et al. 2019). For instance, zinc alginate/nano- $\mathrm{Cu}_{2} \mathrm{O}$ composites exhibited enhanced thermal stability and flame-retardant properties with a limiting oxygen index of 58 compared to zinc alginate. The combustion behavior of the formed CA/calcium borate composites showed excellent anti-dripping properties, while thermogravimetric analysis (TGA) indicated that the formed composites could validly inhibit the heat transmission with more char residue. Nonetheless, the amount of smoke emission for the alginate-based composites was comparatively high based on our previous works. Furthermore, the alginate materials commonly tend to have single function, which cannot fulfill multiple demands and are restrained in practical use (Liu et al. 2018a, 2018b; Xu et al. 2019). Therefore, it is of great significance to synthesize smoke-suppressive flame retardants with multi-functions that are derived from the natural resource of alginate, although it is generally being challenging.

Herein, we report the in-situ synthesis of nanosilver chloride (nano- $\mathrm{AgCl}$ ) in the alginate polysaccharide matrix to obtain the $\mathrm{CA} / \mathrm{AgCl}$ nanocomposites by achieving enhanced flame retardancy and excellent antibacterial properties. The characterization techniques including X-ray diffractometry (XRD), Fourier transform infrared spectroscopy (FT-IR), transmission electron microscopy mapping (TEM-mapping), and TGA was employed to investigate the basic properties of the $\mathrm{CA} / \mathrm{AgCl}$ nanocomposites. The combustion behavior was studied by limiting oxygen index (LOI), vertical burning tests (UL-94), and cone calorimetry (CONE). Moreover, its antibacterial activity was evaluated by the disc diffusion and colony-forming unit (CFU) assay. Furthermore, thermogravimetric analyzer coupled with Fourier transform infrared analysis (TG-FTIR) and pyrolysis-gas chromatography-mass spectrometry (Py-GC-MS) were performed to explore the thermal degradation mechanism, while the fluorescence detection of the reactive oxygen species (ROS) and the images of bacterial morphology change was carried out to illustrate the antibacterial mechanism of materials. Our study presents a facile preparation strategy for alginate-based nanomaterials with dual functions of flame-retardant and antibacterial properties, and also provides deep insights into their functional mechanisms. 


\section{Experimental}

Reagents

Sodium alginate (Viscosity range $105-115 \mathrm{mPa} \cdot \mathrm{s}$, $\left.\mathrm{G} / \mathrm{M}=1.83, \quad \mathrm{M}_{\mathrm{W}}=447,823, \quad \mathrm{M}_{\mathrm{N}}=375,577\right)$ was obtained from Guangfu Fine Chemical Research Institute (Tianjin, China). Silver nitrate, calcium chloride anhydrous and ammonia solution were purchased from Sinopharm Chemical Regent Co., Ltd (Shanghai, China). All the chemicals were of analytical grade and applied without further purification.

Preparation of CA.

In brief, $3 \mathrm{~g}$ of sodium alginate was added to $100 \mathrm{~mL}$ deionized water at $50{ }^{\circ} \mathrm{C}$ for $2 \mathrm{~h}$ with constant stirring to form a homogenous sol, which was shaped by a certain mold and immersed in $1 \mathrm{~L}$ of $4 \%$ calcium chloride solution for $4 \mathrm{~h}$. Finally, the crosslinked gel was washed with distilled water for three times and dried to obtain CA.

\section{Preparation of $\mathrm{CA} / \mathrm{AgCl}$ nanocomposites}

The $\mathrm{CA} / \mathrm{AgCl}$ was prepared through a simple and green method as illustrated in Scheme 1. Briefly, $3 \mathrm{~g}$ of sodium alginate was dissolved in $100 \mathrm{~mL}$ deionized water at $50{ }^{\circ} \mathrm{C}$ for $2 \mathrm{~h}$ with constant stirring to form a homogenous sol. Subsequently, $0.3 \mathrm{~g} \mathrm{AgNO}_{3}$ was dissolved in $10 \mathrm{~mL} \mathrm{H}_{2} \mathrm{O}$, and the ammonia solution was added dropwise until the solution became clear. Then the freshly prepared silver ammonia solution (0.3 $\mathrm{g} \mathrm{AgNO}_{3}, 5 \mathrm{~mL} \mathrm{H} \mathrm{H}_{2} \mathrm{O}, 0.45 \mathrm{~mL}$ ammonia solution, $25{ }^{\circ} \mathrm{C}$ ) was added dropwise under constant stirring for $5 \mathrm{~min}$ and aged for $30 \mathrm{~min}$. The sol was poured into the mold, and then immersed in the calcium chloride solution $\left(30 \mathrm{~g} / \mathrm{L}, 25^{\circ} \mathrm{C}, 4 \mathrm{~h}\right)$ for crosslinking. Finally, the obtained transparent hydrogel was washed with distilled water and dried with freezer dryer (FD-1A-50, Billing Instrument Manufacturing, China) to obtain the $\mathrm{CA} / \mathrm{AgCl}$ nanocomposites.

As shown in Scheme 1, during the calcification process, both calcium and sodium ions were replaced in situ, the structure of the alginic acid macromolecular chain remained unchanged, and the functional groups on the M-block and G-block formed intermolecular hydrogen bonds with the cross-linked $\mathrm{AgCl}$. Therefore, the spatial structure of the formed $\mathrm{CA} / \mathrm{AgCl}$ nanocomposites became more durable.

Characterizations

The XRD (D8 ADVANCE, Bruker, Germany) was occupied to analyze the components of the nanocomposites with Ni-filtered $\mathrm{Cu}-\mathrm{K} \alpha$ radiation $(\lambda=0.154 \mathrm{~nm})$ in the range of $5^{\circ}-80^{\circ}(2 \theta)$. FT-IR (NICOLET iS50, Thermo Fisher Scientific, USA) was employed to detect changes among functional groups
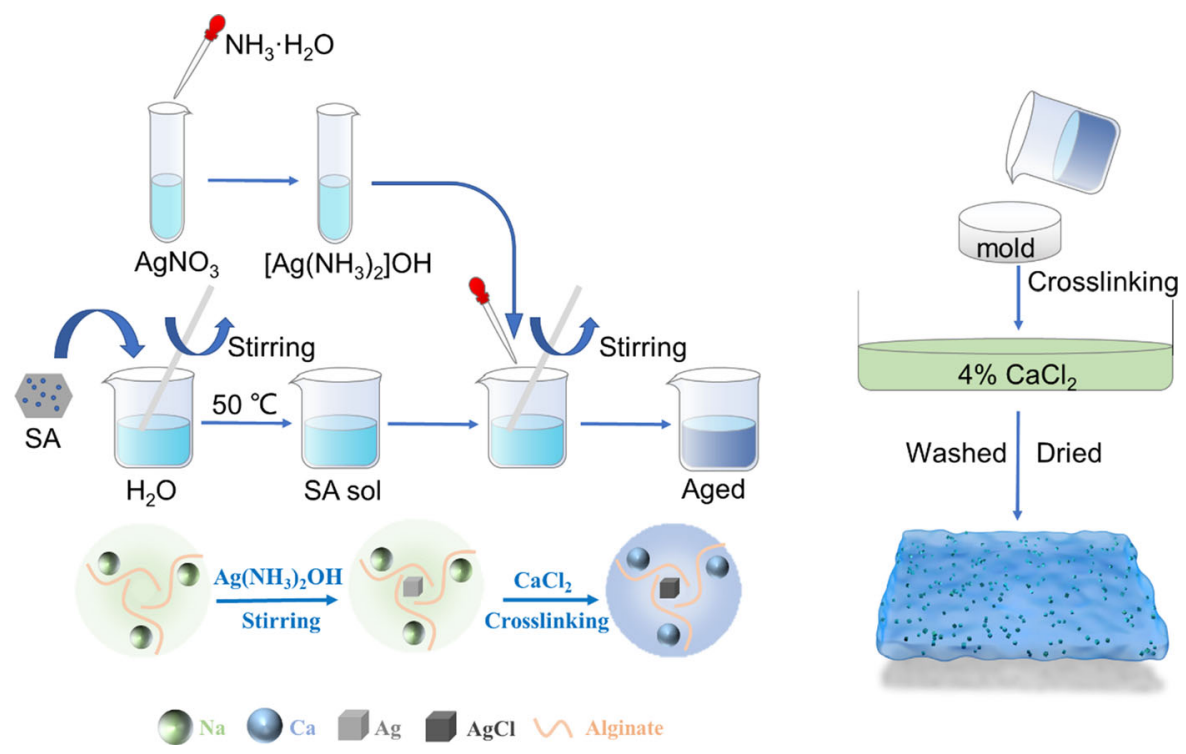

Scheme 1 Schematic illustration for the preparation of $\mathrm{CA} / \mathrm{AgCl}$ nanocomposites 
in the matrix of alginate biopolymer. The representative elements and distribution of $\mathrm{CA} / \mathrm{AgCl}$ were exhibited by TEM-mapping (Tecnai G2 F20, FEI, USA). The morphologies of the $\mathrm{CA}$ and $\mathrm{CA} / \mathrm{AgCl}$ were observed by TEM (XMAX 80 T, Oxford, USA). TGA was performed on a thermal analyzer (SDT Q600, TA Instruments, USA) under both air and nitrogen atmosphere, while the sample was heated from room temperature to $800{ }^{\circ} \mathrm{C}$ at a heating rate of $10{ }^{\circ} \mathrm{C} / \mathrm{min}$ in nitrogen atmosphere.

Flame retardant performances

\section{LOI and UL-94 tests}

The LOI tests were performed on a digital limiting oxygen index tester (LFY-606B, Shandong Textile Science Research Institute, China) according to ISO 4589-1:1996. The UL-94 tests were performed on a burning rate tester (LFY-601A, Shandong Textile Science Research Institute, China) according to ANST/UL-94-1985.

\section{CONE}

The combustion behavior was examined by a cone calorimeter (FTT0242, Fire Testing Technology, UK) under an external heat flux of $50 \mathrm{~kW} / \mathrm{m}^{2}$, according to ISO 5660. The dimensions of all samples were $100 \mathrm{~mm} \times 100 \mathrm{~mm} \times 2 \mathrm{~mm}$.

\section{TG-FTIR}

TG-FTIR measurements were conducted by a TG analyzer (STA6000, PerkinElmer instruments, USA) coupled with a FTIR spectrometer (Perkin-Elmer Frontier, USA). The sample was heated from 30 to $700{ }^{\circ} \mathrm{C}$ in nitrogen atmosphere with a gas flow rate of $50 \mathrm{~mL} / \mathrm{min}$ and the heating rate of $20^{\circ} \mathrm{C} / \mathrm{min}$.

$P y-G C-M S$

Py-GC-MS was tested via a pyrolysis analyzer (EGA/ PY-3030D, Frontier, Japan) coupled with a gas chromatograph (Trace 1310, Thermo Scientific, USA). The composites were processed under a heating rate of $20^{\circ} \mathrm{C} / \mathrm{min}$ in helium atmosphere, and then the products were compared with the National Institute of
Standards and Technology (NIST) library and others standard database library.

Antibacterial tests

The disc diffusion and colony-forming assays were performed to examine the antibacterial activities of $\mathrm{CA}$ and $\mathrm{CA} / \mathrm{AgCl}$. E. coli (ATCC 25922) was cultivated in lysogenic broth medium and $S$. aureus (ATCC 6538) was grown in $7.5 \%$ of sodium chloride broth medium at $37{ }^{\circ} \mathrm{C}$ overnight, respectively.

Disc diffusion assay

The tests for the inhibition zone were based on AATCC-90 (Halo Test) (Zhang et al. 2018a). The sterilized plate agar was poured into petri dishes and cooled. Subsequently, $50 \mu \mathrm{L}$ suspension of $E$. coli and $S$. aureus was spread on the agar surface evenly. Then the hydrogel was subjected to the plate agar surface and incubated at $37{ }^{\circ} \mathrm{C}$ in darkness for $24 \mathrm{~h}$. The effect of the inhibition zone can be judged by preliminary observation. The antibacterial activity of the samples was evaluated by a method reported in the literature, in which the antibacterial action was rated "good" (zone of inhibition $>1 \mathrm{~mm}$ ), "fairly good" (zone of inhibition $\leq 1 \mathrm{~mm}$ ), "sufficient" (growth up to, but not on the hydrogel), "limited" (limited growth on the hydrogel) or "poor" (hydrogel is overgrown with bacteria $\geq 50 \%$ ) (Pollini et al. 2009). The zone of inhibition was expressed as the diameter of no bacterial growth minus the diameter of the hydrogel. The inhibition zone can directly show the antibacterial properties of the nanocomposites.

\section{Colony-forming unit assay}

$\mathrm{CA} / \mathrm{AgCl}$ was dissolved in phosphate buffer saline (PBS) to obtain a $10 \mathrm{mg} / \mathrm{L}$ of solution. The bacterial

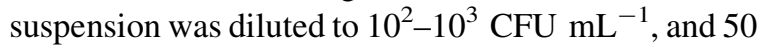
$\mu \mathrm{L}$ mixed solution was pipetted to mix with the dissolved one. After incubation, the mixed solution was pipetted to be cultivated at $37^{\circ} \mathrm{C}$ overnight. Finally, the number of colonies was counted and the percentage of inhibition rate was expressed as the following Eq. (1) (Sedighi and Montazer 2016):

Antibacterial percentage $=($ control group-experimental group)/control group $\times 100 \%$ 

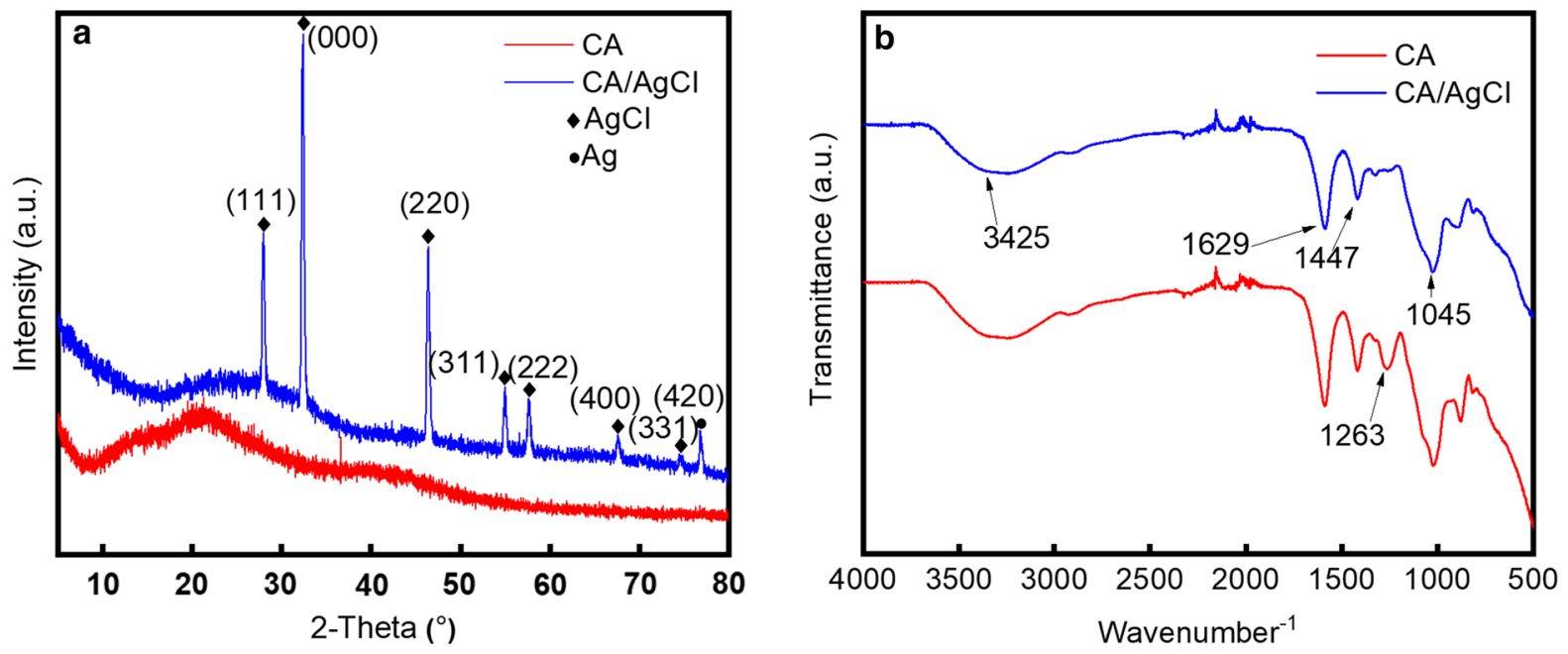

Fig. 1 XRD patterns (a) and FT-IR spectra (b) of CA and CA/AgCl

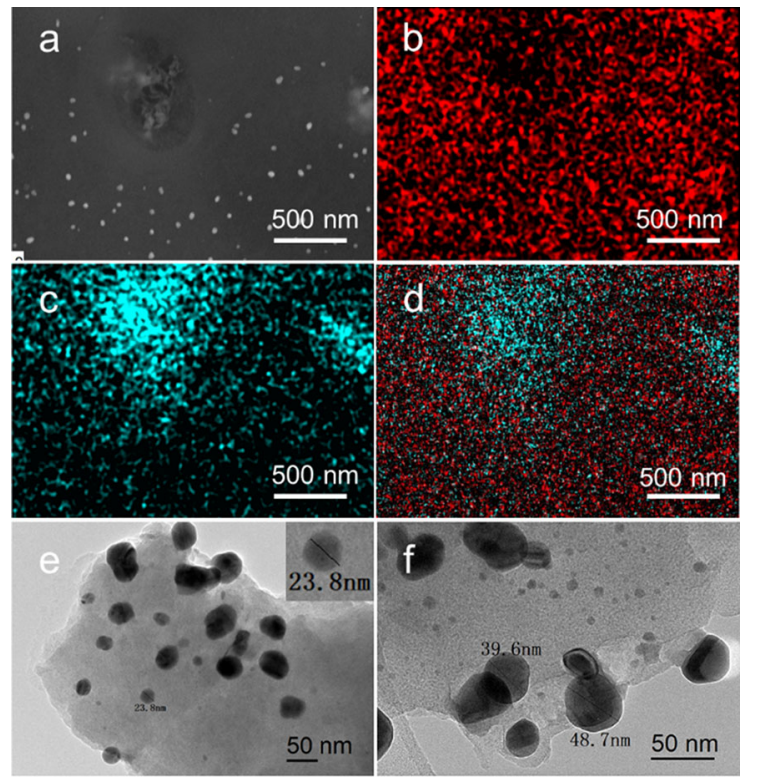

Fig. 2 Selective area TEM image of $\mathrm{CA} / \mathrm{AgCl}$ (a); elemental mapping images of $\mathrm{Ca}(\mathbf{b}), \mathrm{Ag}(\mathbf{c})$, elements superimposed images (d); and TEM images of the typical $\mathrm{CA} / \mathrm{AgCl}$ nanocomposites $(\mathbf{e}, \mathbf{f})$

All the materials were sterilized in an autoclave before tests. Each sample was performed in triplicate and the results were expressed as the mean (Gao et al. 2019).
Microstructural changes of the bacteria

Bio-scanning electron microscope (bio-SEM) (SU8010, Hitachi, Japan) was generally applied to observe the deformation and damage of the outer surface of cells, which also showed the distribution of the antibacterial agents on the cell surface. The bacterial suspension was treated with $\mathrm{CA} / \mathrm{AgCl}$ and washed with $\mathrm{PBS}(\mathrm{pH}=7.4)$ after centrifugation at $3000 \mathrm{r} / \mathrm{min}$ for $10 \mathrm{~min}$. The concentrated bacterial colonies were collected and fixed with $2.5 \%$ glutaraldehyde at $4{ }^{\circ} \mathrm{C}$ for overnight. Bacterial cells were dehydrated with graded ethanol. The sample was placed on the conductive glue and dried for observation. For comparison, the untreated bacteria were selected as the control group.

\section{Detection of reactive oxygen species (ROS)}

The release level of ROS was detected by the fluorescence label $2^{\prime}, 7^{\prime}$-dichlorodihydrofluorescein diacetate (DCFH-DA) (CAS: 4091-99-0). Briefly, the bacteria were treated with DCFH-DA in dark for $30 \mathrm{~min}$. The experimental groups were treated with $\mathrm{CA} / \mathrm{AgCl}$ for 15 and $30 \mathrm{~min}$, respectively. Then the samples were rinsed with PBS for several times. Finally, the generation of ROS and the fluorescent images were analyzed with a confocal microscope (FV1200, Olympus, Japan). 

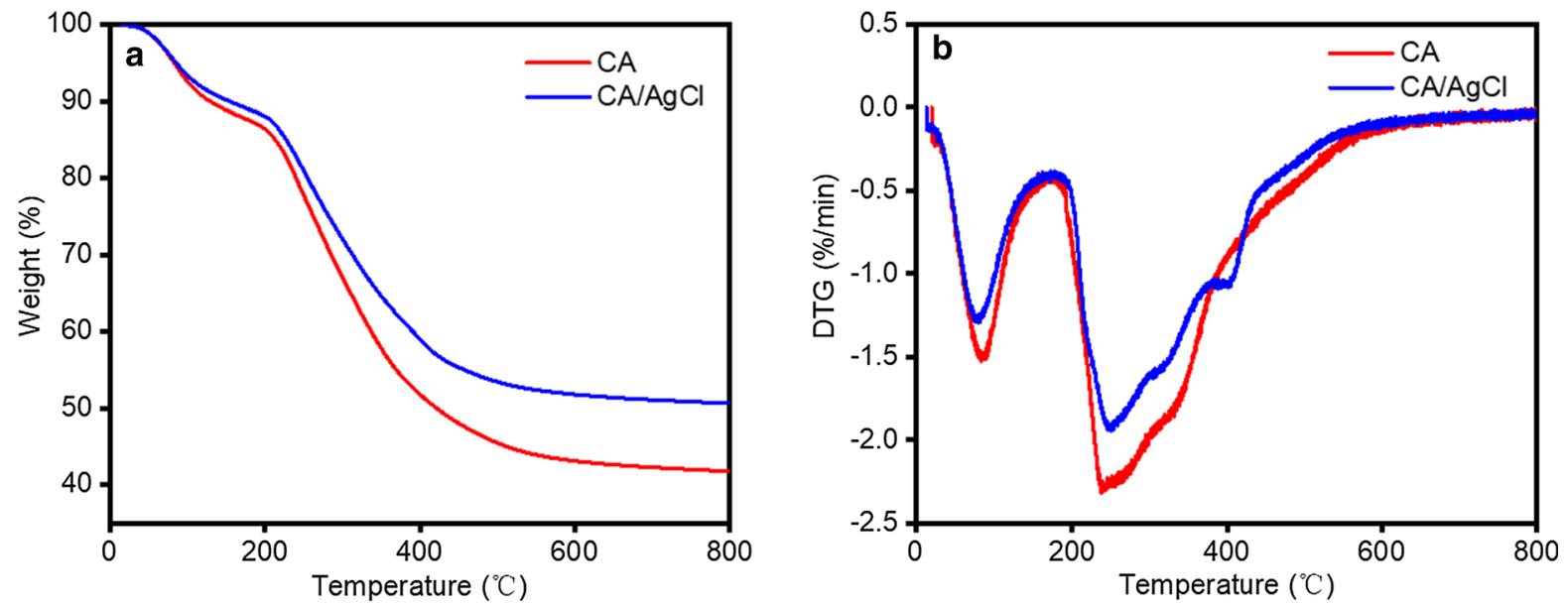

Fig. 3 TGA (a) and DTG (b) curves of CA and CA/AgCl under $\mathrm{N}_{2}$

Table 1 Main data of TG and DTG analysis

\begin{tabular}{llllll}
\hline Samples & $\mathrm{T}_{5 \%}\left({ }^{\circ} \mathrm{C}\right)$ & $\mathrm{T}_{10 \%}\left({ }^{\circ} \mathrm{C}\right)$ & $\mathrm{T}_{\max 1}\left({ }^{\circ} \mathrm{C}\right)$ & $\mathrm{T}_{\max 2}\left({ }^{\circ} \mathrm{C}\right)$ & Residue at $700{ }^{\circ} \mathrm{C}(\%)$ \\
\hline $\mathrm{CA}$ & $83 \pm 2$ & $129 \pm 3$ & $82 \pm 4$ & $238 \pm 2$ & $42.9 \pm 0.3$ \\
$\mathrm{CA} / \mathrm{AgCl}$ & $85 \pm 3$ & $154 \pm 1$ & $87 \pm 2$ & $257 \pm 1$ & $51.7 \pm 0.5$ \\
\hline
\end{tabular}

Table 2 LOI, UL-94 and combustion parameters of CA and CA/AgCl

\begin{tabular}{lllllrl}
\hline Sample & LOI $(\%)$ & UL-94 & THR $\left(\mathrm{MJ} / \mathrm{m}^{2}\right)$ & PHRR $\left(\mathrm{kW} / \mathrm{m}^{2}\right)$ & TSR $\left(\mathrm{m}^{2} / \mathrm{m}^{2}\right)$ & Residue $(\%)$ \\
\hline CA & $48 \pm 1$ & V-0 & $2.5 \pm 0.1$ & $53 \pm 4$ & $30.0 \pm 1.2$ & $33.1 \pm 0.8$ \\
CA $/ \mathrm{AgCl}$ & $>60$ & V-0 & $2.4 \pm 0.1$ & $12 \pm 1$ & $2.7 \pm 0.5$ & $47.4 \pm 0.3$
\end{tabular}

*LOI, limiting oxygen index; UL-94, vertical burning test; THR, total heat release; PHRR, peak heat release rate; TSR, total smoke release
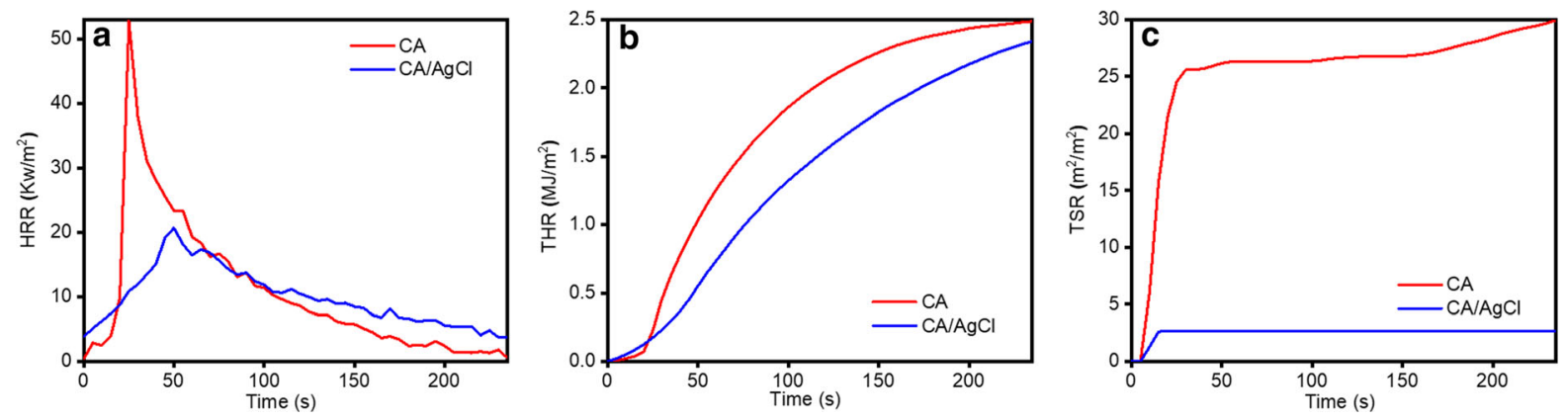

Fig. 4 HRR, THR and TSR curves of CA and CA/AgCl trend with time 
Statistical analysis

Results were expressed as a mean value with standard deviation (mean \pm S.D.) of each sample that is repeated three times and the results were expressed as the mean.

\section{Results and discussion}

\section{Characterizations of $\mathrm{CA} / \mathrm{AgCl}$}

The XRD patterns of $\mathrm{CA}$ and $\mathrm{CA} / \mathrm{AgCl}$ are shown in Fig. 1a. The peaks at $2 \theta=27.8^{\circ}(111), 32.2^{\circ}(000)$, $46.3^{\circ}(220), 54.8^{\circ}(311), 57.6^{\circ}(222), 67.4^{\circ}$ (400), $74.5^{\circ}(331)$, and $76.6^{\circ}(420)$ are attributed to the typical cubic phase of metallic AgCl (JCPDS file:311238), which identify the formation of $\mathrm{AgCl}$ crystals (Zhang et al. 2018a). The FT-IR absorption peaks of $\mathrm{CA}$ and $\mathrm{CA} / \mathrm{AgCl}$ are displayed in Fig. 1b, in which the broad peaks at $3425 \mathrm{~cm}^{-1}$ are ascribed to the stretching vibration of the $-\mathrm{OH}$ bond. The peak at $1629 \mathrm{~cm}^{-1}$ corresponds to the vibration of the $-\mathrm{COO}$ bond (Zhao et al. 2018), and the peak at $1447 \mathrm{~cm}^{-1}$ is attributed to the $-\mathrm{CH}_{2}$ bond, while the peak at $1045 \mathrm{~cm}^{-1}$ is assigned to the $\mathrm{C}-\mathrm{O}-\mathrm{C}$ bond (Luo et al. 2015). In addition, it can be observed that the absorption peaks of the nanocomposites at 1629, 1263 and $1045 \mathrm{~cm}^{-1}$ are weakened, which may be related to the change of the force field around the hydrogen atoms after the formation of hydrogen bonds, while the absorption peaks shift to low frequencies. The absorption peaks at 1263 and $1447 \mathrm{~cm}^{-1}$ can be assigned to the stretching vibration of the $\mathrm{C}-\mathrm{O}$ bond. All the above-presented results indicate the successful synthesis of $\mathrm{CA} / \mathrm{AgCl}$ nanocomposites.
TEM was performed to explore the distribution of $\mathrm{AgCl}$ NPs in CA matrix and the results are shown in Fig. 2. It can be seen from Fig. 2a that $\mathrm{AgCl}$ NPs are dispersed in the continuous phase of CA. Figure $2 b, c$ reveal the distribution of calcium and silver elements, respectively. The superimposed images of calcium and silver element are displayed in Fig. 2d. It can be observed that they are hybridized with each other, and the distribution is relatively uniform. As seen in Fig. 2e, f, the morphology of nano- $\mathrm{AgCl}$ is monodispersed with a size from 20 to $50 \mathrm{~nm}$, suggesting that the simple green in-situ synthetic process successfully avoid the agglomeration of nano- $\mathrm{AgCl}$. We suggest that the positioning effect of carboxyl groups on anions as well as the entanglement and stabilization effects of macromolecular chains on NPs contribute to the formation of non-agglomerated nano- $\mathrm{AgCl}$.

The thermal stability of both $\mathrm{CA}$ and $\mathrm{CA} / \mathrm{AgCl}$ under nitrogen atmosphere was investigated by TGDSC and the curves are plotted in Fig. 3 with the main data listed in Table 1. It can be found that both samples display similar reaction trends. The original weight losses $\left(\mathrm{T}_{5 \%}\right)$ of $\mathrm{CA}$ and $\mathrm{CA} / \mathrm{AgCl}$ appeared at 83 and $85{ }^{\circ} \mathrm{C}$, respectively. In the initial stage, the temperature of maximum rate $\left(\mathrm{T}_{\max 1}\right)$ was 82 and $87{ }^{\circ} \mathrm{C}$, which are ascribed to the loss of crystal water and free water. However, in the second stage, their rates of weightlessness were accelerated in two independent decomposition steps at $90-647{ }^{\circ} \mathrm{C}$ and $87-701{ }^{\circ} \mathrm{C}$, respectively, which can be ascribed to the decomposition of alginate. As a typic organic substance, CA shows weight loss $\mathrm{T}_{\max 2}$ at $238{ }^{\circ} \mathrm{C}$, while obtaining char residue about $42.9 \%$. As for $\mathrm{CA} / \mathrm{AgCl}$, the second stage has a higher char residue of about $51.7 \%$ at $\mathrm{T}_{\max 2}$ of $257{ }^{\circ} \mathrm{C}$. Furthermore, the char residue increased by $8.8 \%$, which can be assigned to the catalysis of $\mathrm{AgCl}$

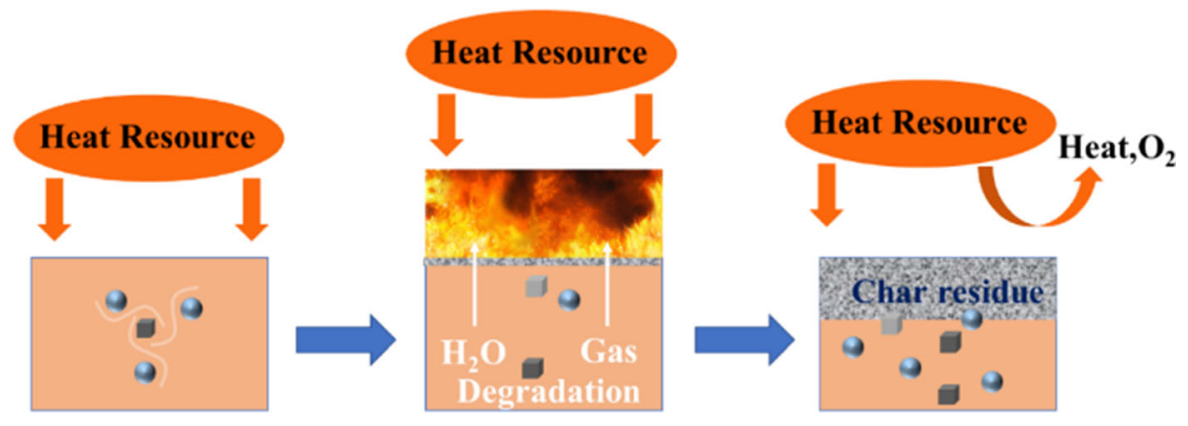

Fig. 5 Schematic diagram of char residue layer formation 


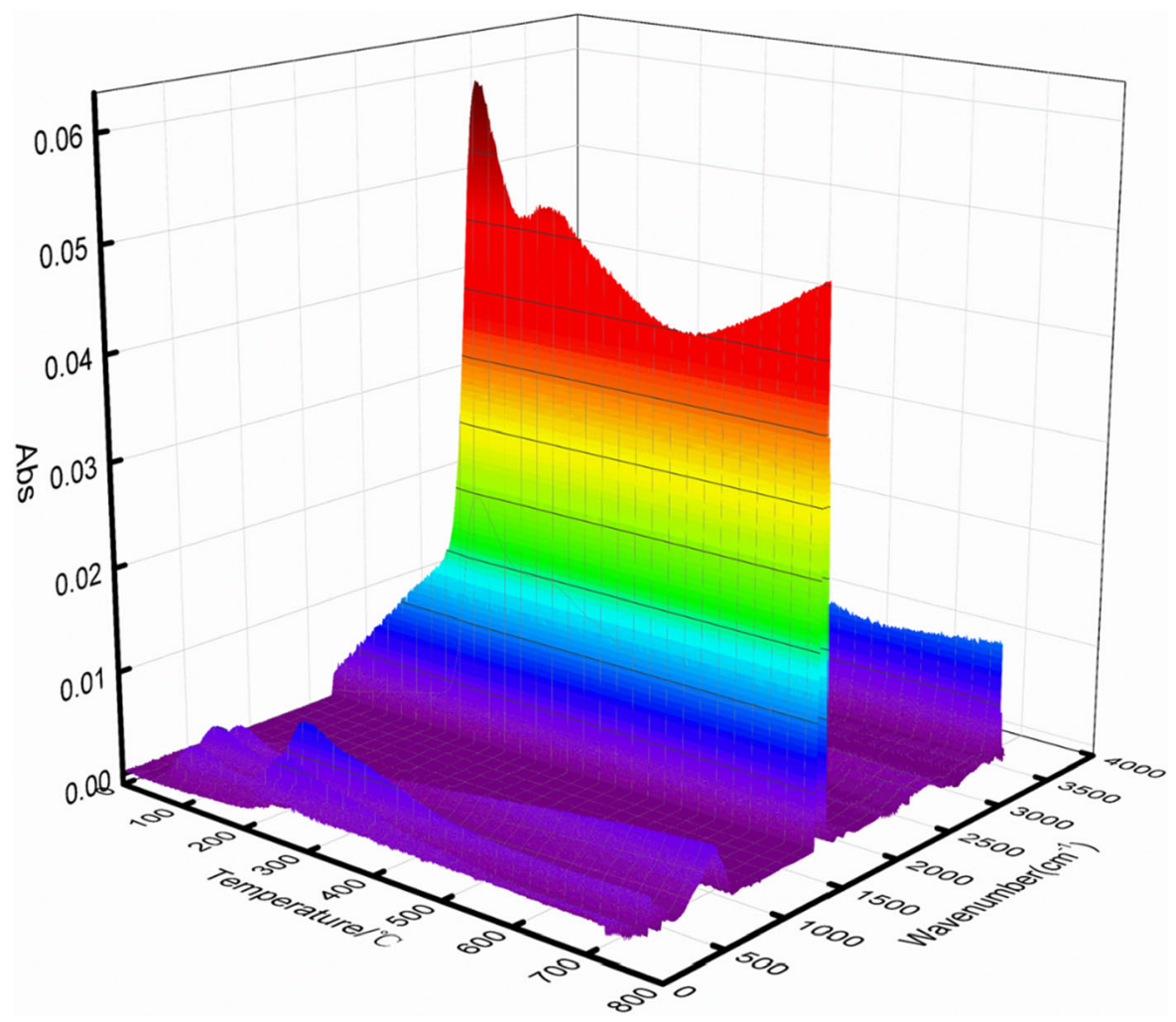

Fig. $63 \mathrm{D}$ image of $\mathrm{CA} / \mathrm{AgCl}$ nanocomposites obtained from TG-FTIR

for promoting the formation of char residue. The presence of $\mathrm{AgCl}$ reduces the thermal decomposition rate of the nanocomposites and catalyze organic matter to form a char residue layer, thus improving their flame-retardant properties. The increase of the char residue ratio indicates that the combustion part was reduced and the flame-retardant property for the nanocomposites was improved.

Flame-retardant performance

\section{LOI, UL-94 and CONE tests}

The flame-retardant property was studied by the LOI and UL-94 tests and the data are displayed in Table 2. Samples were extinguished in $10 \mathrm{~s}$ and maintained their initial shape without dripping, which are classified as V-0. Furthermore, for comparison the LOI value is increased from $48(\mathrm{CA})$ to $60(\mathrm{CA} / \mathrm{AgCl})$, confirming that the introduction of $\mathrm{AgCl}$ markedly enhanced the flame retardancy of CA.
CONE is currently the most ideal test instrument that can characterize the combustion performance of composites. Its test environment is close to the real combustion environment of the fireproof materials, and the obtained test data can evaluate the combustion behavior of composites in fires (Ma et al. 2017). The heat release rate (HRR), total heat release (THR) and total smoke release (TSR) are the important parameters to characterize the fire safety and the spread of fire (Nabipour et al. 2020; Wang et al. 2018). The combustion behavior related data are listed in Table 2 and the curves are depicted in Fig. 4. The peak of the heat release rate (PHRR) and TSR of $\mathrm{CA} / \mathrm{AgCl}$ is much lower than of $\mathrm{CA}$, indicating the better flameretardant performance of the nanocomposites. Meanwhile, the THR of both $\mathrm{CA}$ and $\mathrm{CA} / \mathrm{AgCl}$ are at a low level. In addition, the residue of $\mathrm{CA} / \mathrm{AgCl}(47.4 \%)$ is higher than that of CA $(33.1 \%)$, which corresponded to the data of weight loss in TGA.

$\mathrm{AgCl}$ NPs could catalyze organic matter to form a char residue, which blocked the air and prevented further combustion of the nanocomposites (Mu et al. 

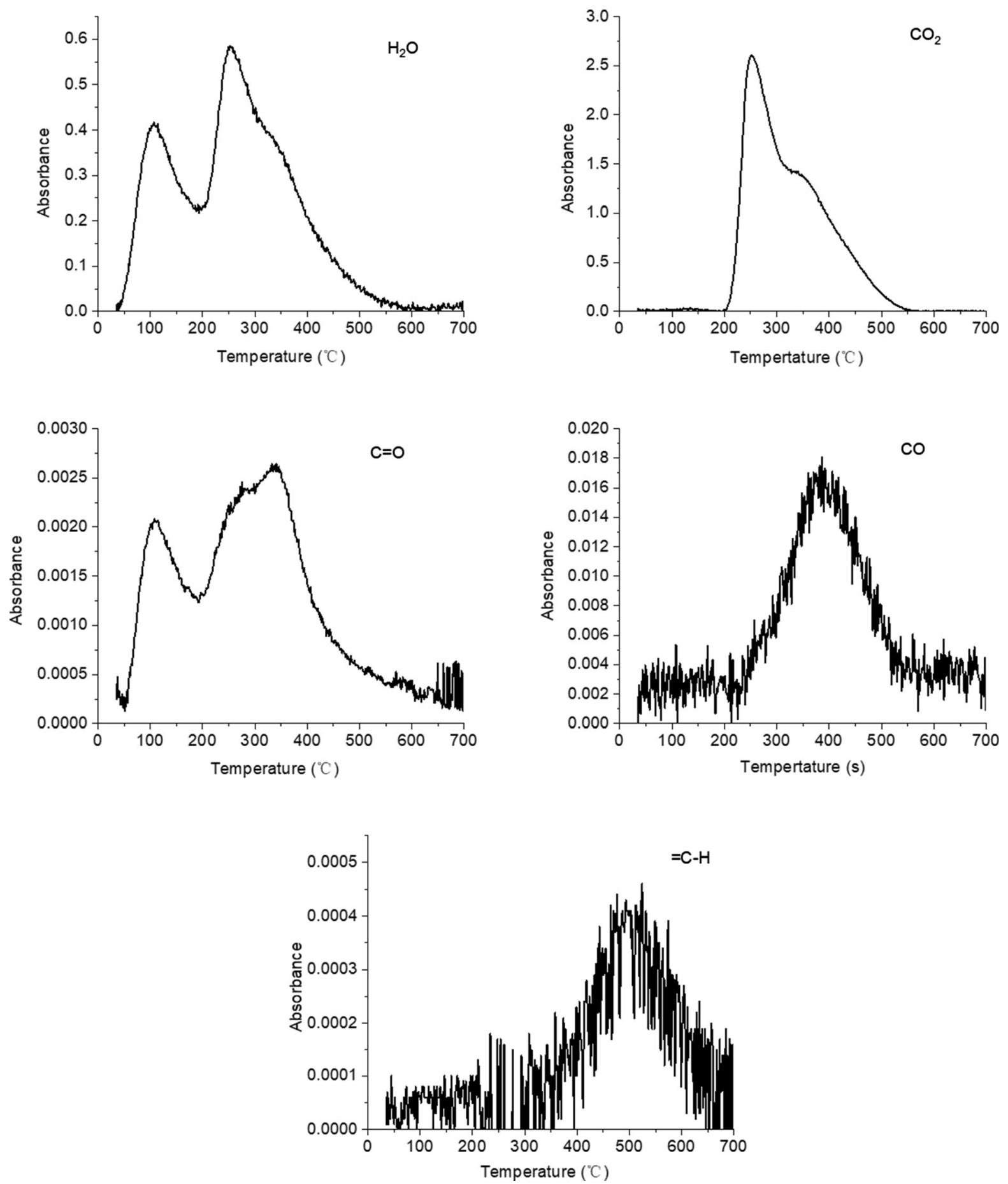

Fig. 7 FT-IR spectra of typical groups as a function of temperature for $\mathrm{CA} / \mathrm{AgCl}$

2017), resulting in a decrease in smoke and heat release (Wang et al. 2016). The formation process of char residue is shown in Fig. 5. In a fire, the smoke is an important cause of casualties, thus low smoke emission is of great importance for protecting human lives. Since the amount of smoke released from CA/ 


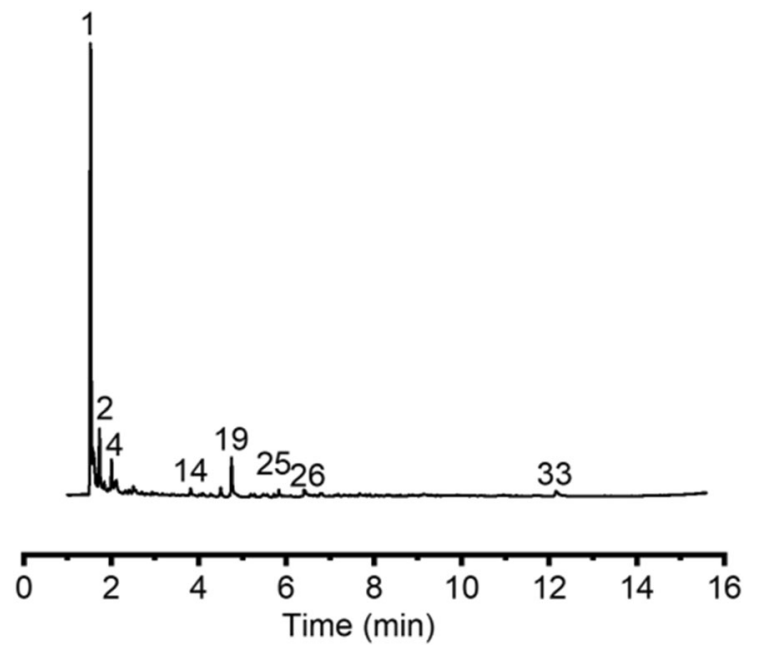

Fig. 8 PY-GC-MS detection of gas products evolved from pyrolysis of $\mathrm{CA} / \mathrm{AgCl}$

$\mathrm{AgCl}$ is $91 \%$ lower than that of $\mathrm{CA}$, we suggest that $\mathrm{CA} / \mathrm{AgCl}$ is an excellent low-smoke composite. The aforementioned results indicate that $\mathrm{CA} / \mathrm{AgCl}$ possess much better flame-retardant property than that of CA.

\section{TG-FTIR}

TG-FTIR was employed to study the thermal degradation performance of $\mathrm{CA} / \mathrm{AgCl}$ nanocomposites. Figure 6 shows the 3D FTIR spectrum of the gas generated during the thermal degradation of $\mathrm{CA} / \mathrm{AgCl}$ nanocomposites, in which the information of wavenumber, infrared absorbance and time are included.

It can be observed from Fig. 6 that most of the pyrolysis process took place in the temperature range of $228-700{ }^{\circ} \mathrm{C}$, and the main products are $\mathrm{CO}_{2}$ (2364-667 $\mathrm{cm}^{-1}$ ) and $\mathrm{H}_{2} \mathrm{O}\left(3730-3500 \mathrm{~cm}^{-1}\right.$ ) (Wang et al. 2018). In order to further understand the changing trends for the absorbance of various functional groups towards temperature, the infrared spectra of several functional groups were selected for preliminary analysis, as shown in Fig. 7. It can be found that the primary gaseous products are $\mathrm{H}_{2} \mathrm{O}$ and $\mathrm{CO}_{2}$, flammable components released $=\mathrm{CH},-\mathrm{C}=\mathrm{O}, \mathrm{CO}$ groups and wave numbers of the functional group were as following: $\mathrm{H}_{2} \mathrm{O}, \quad 3730 \mathrm{~cm}^{-1} ;=\mathrm{CH}$, $3016 \mathrm{~cm}^{-1} ; \quad \mathrm{CO}_{2}, \quad 2364 \mathrm{~cm}^{-1}$; CO, $2180 \mathrm{~cm}^{-1}$; $\mathrm{C}=\mathrm{O}, 1752 \mathrm{~cm}^{-1}$ (Liu et al. 2015b). The changes of the absorbance of the above functional groups with temperature are shown in Fig. 7. It is clear that $\mathrm{H}_{2} \mathrm{O}$ and $-\mathrm{C}=\mathrm{O}$ are mainly produced in the first and second pyrolysis stages of $\mathrm{CA} / \mathrm{AgCl}$, while $\mathrm{CO}_{2}$ is mainly generated in the second stage of pyrolysis. Meanwhile, the compounds containing $=\mathrm{CH}$ groups mainly appears in the high temperature area (Liu et al. 2016b).

It can be known from Fig. 7 that the $\mathrm{H}_{2} \mathrm{O}$ and $\mathrm{C}=\mathrm{O}$ groups are produced in the primal pyrolysis stage (low-temperature area), and the $=\mathrm{CH}$ fragments are generated in the third pyrolysis stage (hightemperature area) (Zhang et al. 2018b). The absorbance of above functional groups varied with temperature. $\mathrm{H}_{2} \mathrm{O}$ and $\mathrm{CO}_{2}$ are generated at the low temperature and $\mathrm{H}_{2} \mathrm{O}$ is generated a little earlier than $\mathrm{CO}_{2}$, which can be ascribed to the release of crystal water in the nanocomposites. However, the absorbance intensity of $\mathrm{CO}_{2}$ is much higher than that of $\mathrm{H}_{2} \mathrm{O}$, which can be attributed to the catalysis of silver, making thermal degradation preferred to decarboxylation. The $=\mathrm{CH}$ groups are mainly yielded at the high-temperature area, indicating that these compounds have a further degradation stage at the high temperature to release $=\mathrm{CH}$. In addition, $\mathrm{CO}$ occurred in the second pyrolysis stage, and the intensity stays at a high level at the high temperature, suggesting further pyrolysis process can generate $\mathrm{CO}$.

The aforementioned results briefly explain the pyrolysis process, including dehydration, decarboxylation and cleavage. Fractures of glycosidic bonds were emerged at the second pyrolysis stage, with the production of $\mathrm{CO}_{2}, \mathrm{H}_{2} \mathrm{O},-\mathrm{C}=\mathrm{O}$ and char residues. The fragments were pyrolyzed into more stable char residue and released $\mathrm{CO}$ and $=\mathrm{CH}$ groups, when the temperature rose (Zhang et al. 2016).

\section{PY-GC-MS}

The PY-GC-MS analysis was carried out to investigate the pyrolytic gaseous components of $\mathrm{CA} / \mathrm{AgCl}$. Comparing with the NIST library, the highest possibility of gaseous compounds identification was acquired (Liu et al. 2016b). The ion intensities of gaseous products are shown in Fig. 8. The peaks of all the products were marked with labels, which corresponded to the numbers in Table S1 and the main products are listed in Table 3. According to the information in Fig. 8 and Table 3, the major pyrolysis products are identified to be $\mathrm{CO}_{2}$, acetone, 2, 
Table 3 Analytical results of chemical constituents of 700 pyrolysis products of CA/AgCl

\begin{tabular}{|c|c|c|c|c|c|c|}
\hline $\begin{array}{c}\text { Labe } \\
1\end{array}$ & $\begin{array}{c}\mathrm{T}_{\mathrm{R}} \\
(\mathrm{min})\end{array}$ & $\begin{array}{l}\text { Molecular } \\
\text { formula }\end{array}$ & Name of compound & Molecular structure & $\begin{array}{c}\mathrm{Mw} \\
(\mathrm{g} / \mathrm{mol})\end{array}$ & $\begin{array}{c}\text { Peak } \\
\text { area } \\
(\%)\end{array}$ \\
\hline 1 & 1.53 & $\mathrm{CO}_{2}$ & Carbon dioxide & $\mathrm{O}=\mathrm{c}=\mathrm{O}$ & 44 & 57.43 \\
\hline 2 & 1.73 & $\mathrm{C}_{3} \mathrm{H}_{6} \mathrm{O}$ & Acetone & & 58 & 7.06 \\
\hline 3 & 1.84 & $\mathrm{C}_{5} \mathrm{H}_{6}$ & 1,3-Cyclopentadiene & & 66 & 0.77 \\
\hline 4 & 2.01 & $\mathrm{C}_{4} \mathrm{H}_{6} \mathrm{O}_{2}$ & 2,3-Butanedione & & 86 & 2.95 \\
\hline 5 & 2.11 & $\mathrm{C}_{2} \mathrm{H}_{4} \mathrm{O}_{2}$ & Acetic acid & $\mathrm{OH}$ & 60 & 2.33 \\
\hline 6 & 3.81 & $\mathrm{C}_{7} \mathrm{H}_{8}$ & Toluene & & 92 & 1.21 \\
\hline 7 & 4.50 & $\mathrm{C}_{5} \mathrm{H}_{4} \mathrm{O}_{2}$ & 3-Furaldehyde & & 96 & 1.39 \\
\hline 8 & 4.75 & $\mathrm{C}_{5} \mathrm{H}_{4} \mathrm{O}_{2}$ & Furfural & & 96 & 5.61 \\
\hline
\end{tabular}

3-Butanedione, acetic acid, toluene and furfural with the total yields of $78.75 \%$. the dehydration, decarboxylation, disproportionation and ring-opening were related reactions during the pyrolysis process (Liu et al. 2015c). The pyrolysis mechanism of $\mathrm{CA} / \mathrm{AgCl}$ was proposed, as shown in Fig. 9. Alginate molecule was broken into $M$ and $G$ blocks, while the decarboxylation and esterification occurred. However, the yield of $\mathrm{CO}_{2}$ is much higher than other components with the catalysis of $\mathrm{Ag}^{+}$, indicating that the proportion of decarboxylation is higher than that of the dehydration reaction. The fracture of the glycosidic bonds led to many intermediate reactions (Liu et al. 2016a), in which the intermediate compounds are produced by the dehydration, rearrangement, and decarboxylation reactions to obtain small molecules, producing a large amount of $\mathrm{CO}_{2}, \mathrm{H}_{2} \mathrm{O}$, and other lower heat value compounds to improve the flame retardancy of $\mathrm{CA} / \mathrm{AgCl}$.

The main absorption peaks were almost the same, compared to the TG-IR results of CA (Fig. S1 and S2). The absorbance peak of $\mathrm{H}_{2} \mathrm{O}$ is much stronger than $\mathrm{CA}$, and more $\mathrm{CO}_{2}$ was released above $500{ }^{\circ} \mathrm{C}$. In addition, the absorbance of $\mathrm{C}=\mathrm{O}, \mathrm{CO}$ and $=\mathrm{C}-\mathrm{H}$ are much weaker, indicating that less flammable components were released from $\mathrm{CA} / \mathrm{AgCl}$. Hence, the formed $\mathrm{CA} / \mathrm{AgCl}$ nanocomposites exhibit more excellent flame-retardant property. 


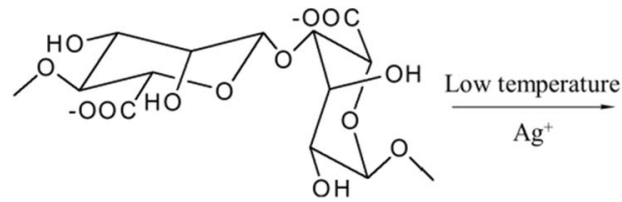

Fig. 9 Speculative pyrolysis mechanism of $\mathrm{CA} / \mathrm{AgCl}$

\section{Antibacterial performance and rate}

The results for the zone of inhibition are shown in Fig. 10. It can be found that CA showed no antibacterial or quite weak antibacterial properties for both E. coli and S. aureus. As seen in Fig. 10a, c, there was no inhibition zone formed around the hydrogels because alginate did not contain antibacterial functional groups. After the combination with $\mathrm{AgCl}$, silver ions played a major antibacterial role in the nanocomposites (De Silva et al. 2018). The width of inhibition area against both of the bacterial strains was larger than $1 \mathrm{~mm}$, as shown in Fig. 10b, d, which exhibited enhanced antibacterial capability. The results of the colony CFU confirmed the data from the agar diffusion experiments.

The control groups of $E$. coli and $S$. aureus colonies

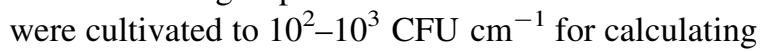
the antibacterial rates. Both $\mathrm{CA}$ and $\mathrm{CA} / \mathrm{AgCl}$ were mixed with bacteria. The colonies were counted and the data are listed in Fig. 10e. Notably, the antibacterial rates of $S$. aureus and E. coli are $99.67 \pm 0.33 \%$ and $99.70 \pm 0.29 \%$ on average, respectively (Boroumand et al. 2015).

E. coli was more sensitive to silver ions than $S$. aureus, which may ascribe to the difference in the cell wall properties of two bacterial strains. For instance, the cell wall of $S$. aureus is very thick and contains a lot of surface components of mucopeptides and phosphatidic acid (Applerot et al. 2012), which can 

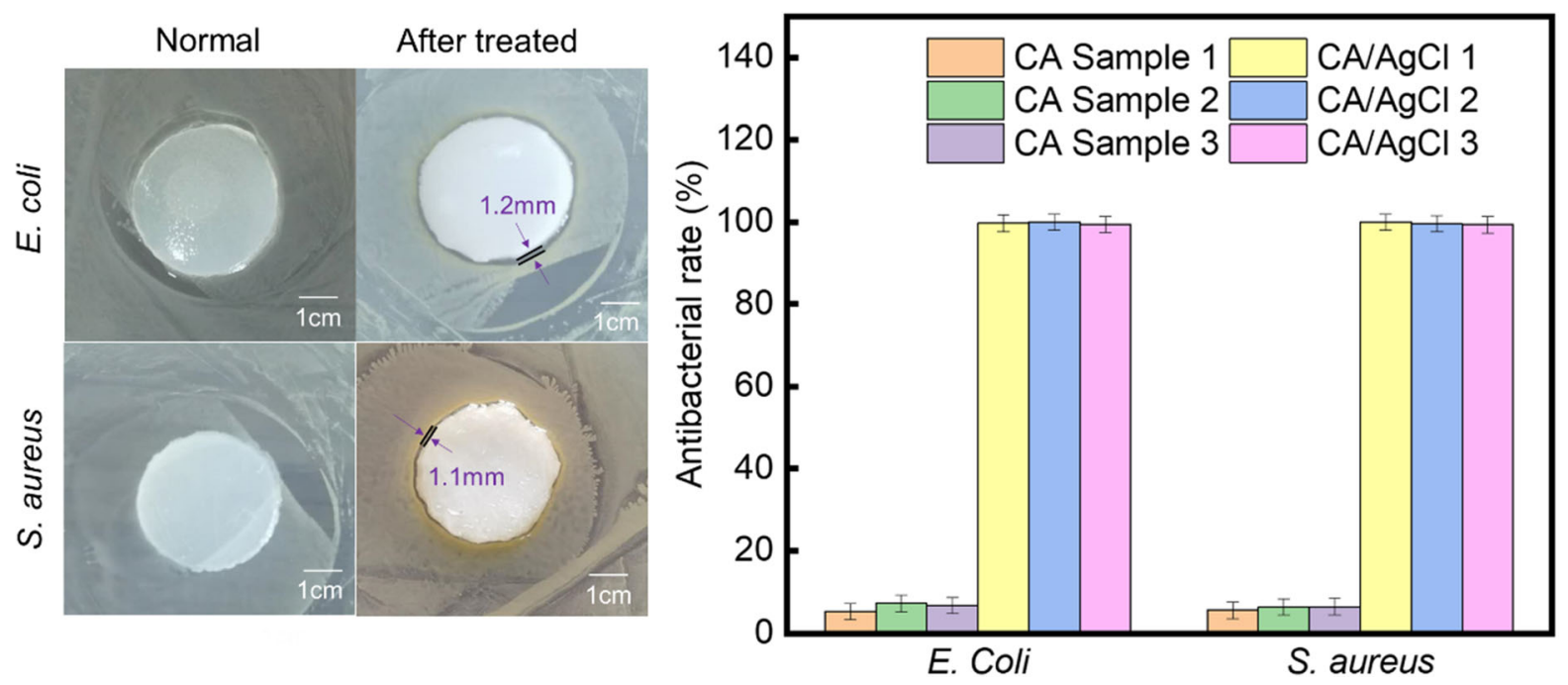

Fig. 10 Inhibition zone of $\mathrm{CA}(\mathbf{a})$ and $\mathrm{CA} / \mathrm{AgCl}(\mathbf{b})$ hydrogel in E. coli medium; inhibition zone of $\mathrm{CA}(\mathbf{c})$ and $\mathrm{CA} / \mathrm{AgCl}(\mathbf{d}) \mathrm{hydrogel}$ in $S$. aureus medium; antibacterial rate in E. coli and S. aureus (e)

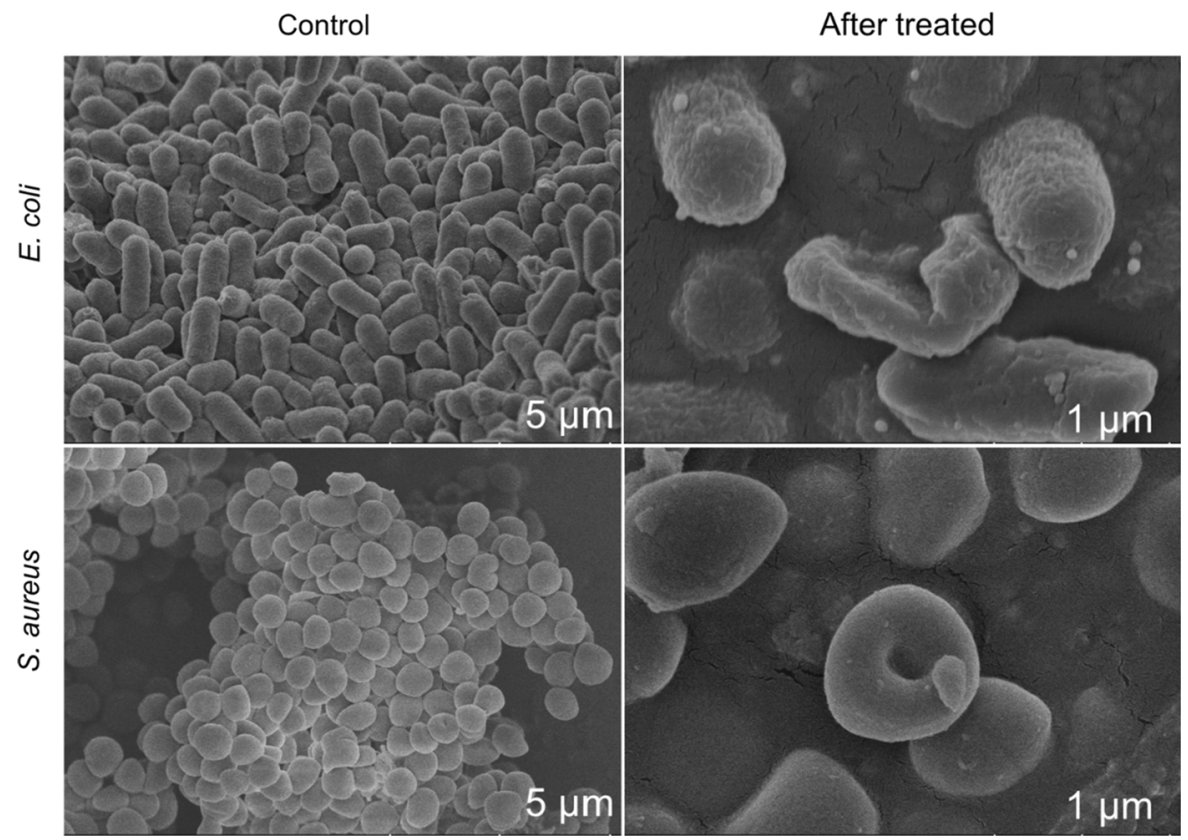

Fig. 11 SEM images for comparison of E. coli and S. aureus after treated with CA/AgCl nanocomposites

be the main reason for resulting the difference in the antibacterial rate.

\section{Microstructure of bacteria}

The morphologies of E. coli and S. aureus treated with $\mathrm{CA} / \mathrm{AgCl}$ and normal status were observed by bio-
SEM, and the results are shown in Fig. 11. Intact E. coli cells are rod-like shape with a rough surface and $S$. aureus cells present spherical shape that was the normal morphology of bacterial growth and a necessary condition for survival. Compared with the image of normal cells, E. coli treated with $\mathrm{CA} / \mathrm{AgCl}$ shows an abnormal wrinkled appearance, while $S$. aureus 
E. coli

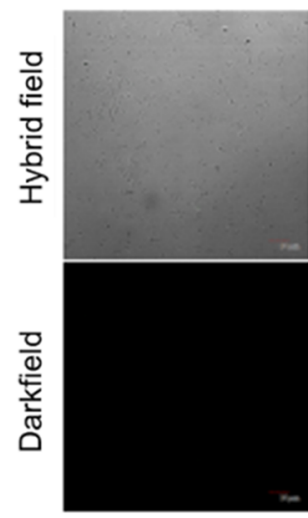

Control

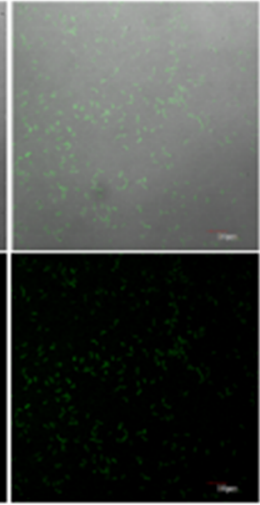

$15 \min$

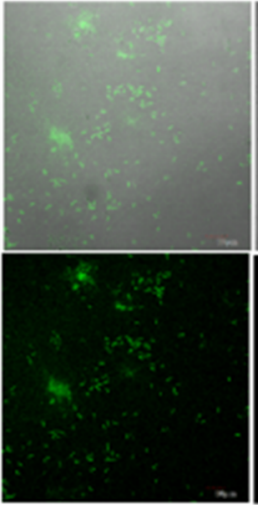

$30 \mathrm{~min}$

S. aureus

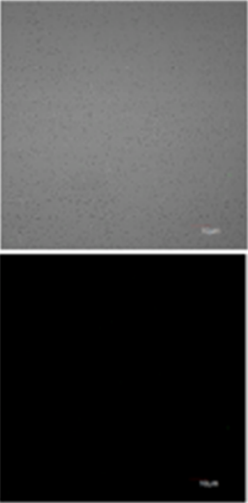

Control

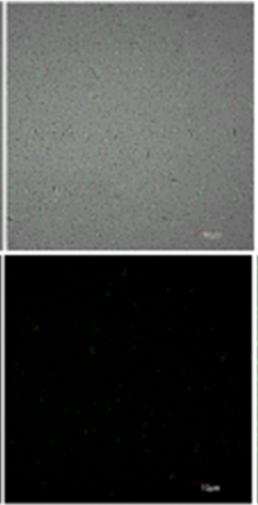

$15 \mathrm{~min}$

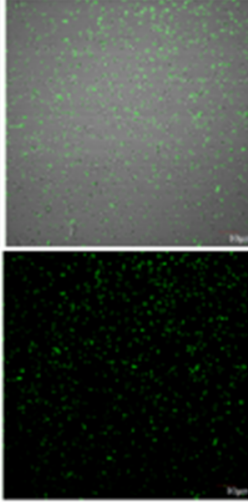

$30 \mathrm{~min}$

Fig. 12 Fluorescence images of E. coli and S. aureus in dark field and hybrid field treated with CA/AgCl nanocomposites for 15 and $30 \mathrm{~min}$ (scale bar: $10 \mu \mathrm{m}$ ), respectively

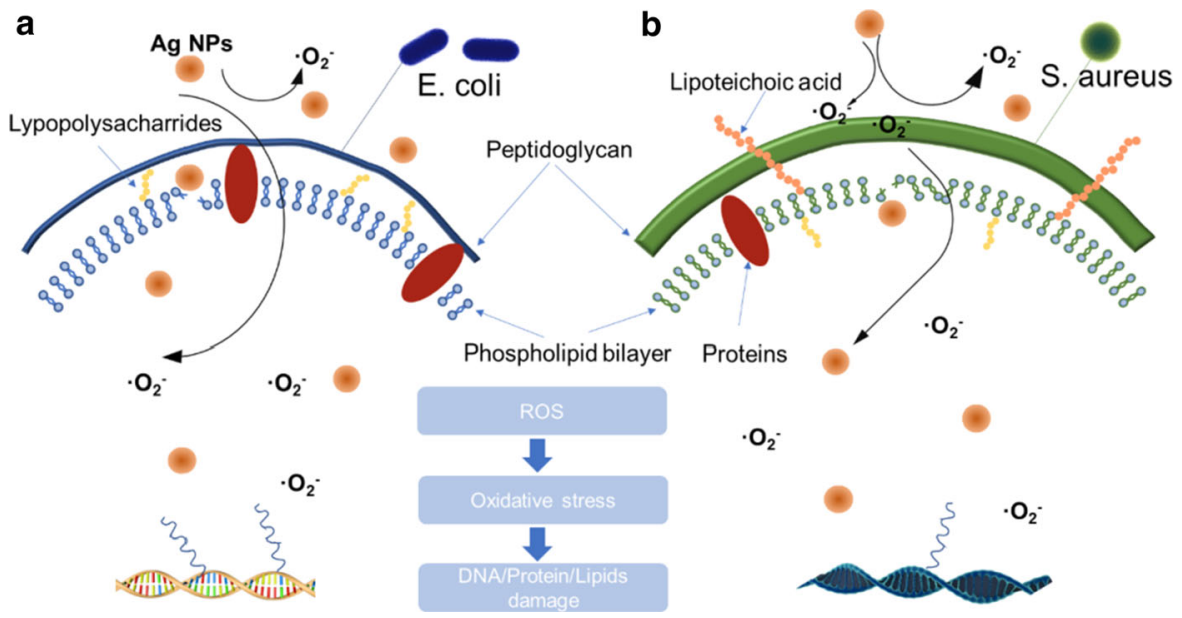

Fig. 13 Schematic illustration of antibacterial mechanism of Ag NPs and 2D structure of E. coli (a) and S. aureus (b)

bacterial membrane becomes concaved and the bacterial substrate was flowed out, reflecting the damage of bacterial cells and the cell internalization (Wu et al. 2018). The leakage of cell contents inevitably led to bacterial death. In addition, larger-sized silver particles were adsorbed on the surface of the cell membrane, which may be caused by the electrostatic interactions between the positively charged particles and the negatively charged functional protein on the cell membrane, as well as the loss of activity indirectly led to cell death. This may be the first step in the operation of the antibacterial mechanism or an auxiliary role.
The release of ROS in bacteria

DCFH-DA itself has no fluorescence and can pass through the cell membrane freely. After entering into the cell, it can be hydrolyzed by esterase in the cell to generate DCFH. However, DCFH cannot penetrate the cell membrane, so that the probe can be easily loaded into the cell. ROS in cells can oxidize non-fluorescent DCFH to produce fluorescent DCF, which can be detected to determine the level of ROS in cells.

The fluorescent probe DCFH-DA was employed to evaluate the intracellular ROS level to further explore the possible antibacterial mechanism (Panda et al. 2018). As seen in Fig. 12, normal cells show almost no 
fluorescence. However, after the treatment with CA/ $\mathrm{AgCl}$ for $15 \mathrm{~min}$, the test samples exhibited weak fluorescence and most of the cells are found to maintain a complete cell structure. S. aureus exhibited weaker fluorescent expression than E. coli did in 15 min, which can be attributed to the difference of membrane. It can be also observed that after cultivating the samples for $30 \mathrm{~min}$, the fluorescence in the field of view taken by the confocal microscope was significantly enhanced. However, the cell structures were destroyed. In addition, the treatment with CA/ $\mathrm{AgCl}$ resulted in obvious increase in the fluorescence intensity. Thus, it can be concluded that the nanocomposites stimulated the release of active oxygen in the cell, and the sterilization mechanism of $\mathrm{CA} / \mathrm{AgCl}$ can be attributed to the production of ROS intermediate products.

\section{Antibacterial mechanism}

Although the antibacterial effect of silver NPs have been extensively studied, a unified sterilization mechanism has not yet been formed, which is still worthy of further discussion (Rai et al. 2012).

Silver NPs can pass through the cell wall to reach to the inside of the bacteria. The oxidase-like properties of noble metals can induce the generation of reactive oxygen species (Cai et al. 2019). The generated ROS results in the internalization reaction of the cell, leading to inactivation of various enzymes, and the oxidative stress reaction causes the cell to commit suicide (Applerot et al. 2012).

Figure 13 shows the general antibacterial mechanisms and the function of silver NPs towards $E$. coli and S. aureus, respectively. Firstly, $\mathrm{AgCl}$ with a lower crystallinity enters into cells through the cell membrane (Mokhena and Luyt 2017b). Then the internalization of the cell leads to the leaching of silver ions and various enzymes react to induce oxidative stress reactions (Xu et al. 2017). Afterward, the abnormal function of various organelles causes cell leakage and death. In addition, the $\mathrm{AgCl} \mathrm{NPs}$ promote the generation of oxygen anions. Especially ROS, such as superoxide anion free radicals $\left(\cdot \mathrm{O}_{2}{ }^{-}\right)$, hydroxyl free radicals $(\cdot \mathrm{OH})$ and hydrogen peroxide $\left(\mathrm{H}_{2} \mathrm{O}_{2}\right)$ are considered to be the main products disrupting cellular homeostasis and dynamic equilibrium causing leakage of cell contents and ultimately bacterial apoptosis (Chen et al. 2019). Furthermore, the ROS can oxidize mediated proteins, lipids and even DNA, and then lead to the loss of general functions of biofilm-related enzymes. Eventually, it causes the death of bacteria. The electrical properties of silver and Gram bacteria are opposite. After the bacteria dies, $\mathrm{AgCl}$ is attracted by other bacteria and continued to react with other bacteria for further repeated cycle.

\section{Conclusions}

$\mathrm{CA} / \mathrm{AgCl}$ nanocomposites were synthesized via a simple and eco-friendly in-situ method. $\mathrm{AgCl}$ in the composites was cubic with a particle size of 20-50 nm, which was evenly distributed in the continuous phase of CA. The formed nanocomposites exhibited excellent flame-retardant property, of which the LOI exceeded 60, and the HRR and THR were significantly reduced. In particular, the amount of released smoke was notably lower than that of CA, which was only $2.7 \mathrm{~m}^{2} / \mathrm{m}^{2}$. It can be concluded that $\mathrm{Ag}^{+}$promoted the formation of char residue and bias towards to decarboxylation during the thermal degradation process. Furthermore, the nanocomposites showed remarkable antibacterial performance. The fluorescence of bacterial cells treated with $\mathrm{CA} / \mathrm{AgCl}$ was significantly enhanced, which proved that the sterilization mechanism of nanocomposites was mainly related to the production of ROS intermediates. Our study proves that the nanocomposites are promising candidates for potential applications in building materials and textile industry.

Acknowledgements This work was supported by the National Natural Science Foundation of China (Grant number 51773102) and State Key Laboratory of Bio-Fibers and Eco-Textiles (Qingdao University, Grant number ZKT20). The authors wish to thank Professor Gang Wei from University of Bremen for his guidance on revising the paper and Dr. Tingting Zhang from Qingdao University for the use of some instruments and assistance with the antibacterial test.

\section{Declaration}

Conflict of interest The authors declared no conflicts of interest. 


\section{References}

Agnieszka Kyzioł JM (2017) Ivan Moreno, Enrique Gamez, Silvia Irusta Preparation and characterization of electrospun alginate nanofibers loaded with ciprofloxacin hydrochloride. Eur Polym J 96:350-360. https://doi.org/ 10.1016/j.eurpolymj.2017.09.020

Applerot G, Lellouche J, Lipovsky A, Nitzan Y, Lubart R, Gedanken A, Banin E (2012) Understanding the antibacterial mechanism of $\mathrm{CuO}$ nanoparticles: revealing the route of induced oxidative stress. Small 8:3326-3337. https:// doi.org/10.1002/smll.201200772

Boroumand MN, Montazer M, Simon F, Liesiene J, Šaponjic Z, Dutschk V (2015) Novel method for synthesis of silver nanoparticles and their application on wool. Appl Surf Sci 346:477-483. https://doi.org/10.1016/j.apsusc.2015.04. 047

Cai T, Fang G, Tian X, Yin JJ, Chen C, Ge C (2019) Optimization of antibacterial efficacy of noble-metal-based core-shell nanostructures and effect of natural organic matter. ACS Nano 13:12694-12702. https://doi.org/10. 1021/acsnano.9b04366

Chen Y, Tang X, Gao X, Zhang B, Luo Y, Yao X (2019) Antimicrobial property and photocatalytic antibacterial mechanism of the $\mathrm{TiO} 2$-doped $\mathrm{SiO} 2$ hybrid materials under ultraviolet-light irradiation and visible-light irradiation Ceram Int 45:15505-15513. https://doi.org/10.1016/j. ceramint.2019.05.054

Das D, Bang S, Zhang S, Noh I (2017) Bioactive molecules release and cellular responses of alginate-tricalcium phosphate particles hybrid gel Nanomaterials (Basel) 7 . https://doi.org/10.3390/nano7110389

De Silva RT et al (2018) Drug-loaded halloysite nanotube-reinforced electrospun alginate-based nanofibrous scaffolds with sustained antimicrobial protection. ACS Appl Mater Inter 10:33913-33922. https://doi.org/10.1021/acsami. 8 b11013

Gao L et al. (2019) Preparation, characterization and antibacterial activity of silver nanoparticle/graphene oxide/diatomite composite Appl Surf Sci 484:628-636. https://doi. org/10.1016/j.apsusc.2019.04.153

Googerdchian F, Moheb A, Emadi R (2012) Lead sorption properties of nanohydroxyapatite-alginate composite adsorbents Chem Eng J 200-202:471-479. https://doi.org/ 10.1016/j.cej.2012.06.084

Kou J, Varma RS (2012) Beet juice-induced green fabrication of plasmonic $\mathrm{AgCl} / \mathrm{Ag}$ nanoparticles. Chemsuschem 5:2435-2441. https://doi.org/10.1002/cssc.201200477

Lee $\mathrm{H}$ et al. (2015) As(III) and As(V) removal from the aqueous phase via adsorption onto acid mine drainage sludge (AMDS) alginate beads and goethite alginate beads $\mathrm{J}$ Hazard Mater 292:146-154. https://doi.org/10.1016/j. jhazmat.2015.03.026

Lee KY, Mooney DJ (2012) Alginate: properties and biomedical applications Prog Polym Sci 37:106-126. https://doi.org/ 10.1016/j.progpolymsci.2011.06.003

Li D, Lv C, Liu L, Xia Y, She X, Guo S, Yang D (2015) Egg-box structure in cobalt alginate: a new approach to multifunctional hierarchical mesoporous $\mathrm{N}$-doped carbon nanofibers for efficient catalysis and energy storage. ACS Cent Sci 1:261-269. https://doi.org/10.1021/acscentsci.5b00191

Li J, Li Z, Zhao X, Deng Y, Xue Y, Li Q (2017a) Flame retardancy and thermal degradation mechanism of calcium alginate/CaCO3 composites prepared via in situ method $\mathrm{J}$ Therm Anal Calorim 131:2167-2177. https://doi.org/10. 1007/s10973-017-6767-5

Li Q et al (2017) Filtration and adsorption properties of porous calcium alginate membrane for methylene blue removal from water. Chem Eng J 316:623-630. https://doi.org/10. 1016/j.cej.2017.01.098

Liu Y et al (2015) Thermal degradation and pyrolysis behavior of aluminum alginate investigated by TG-FTIR-MS and Py-GC-MS. Polym Degrad Stab 118:59-68. https://doi. org/10.1016/j.polymdegradstab.2015.04.010

Liu Y, Wang JS, Zhu P, Zhao JC, Zhang CJ, Guo Y, Cui L (2016a) Thermal degradation properties of biobased iron alginate film. J Anal Appl Pyrol 119:87-96. https://doi.org/ 10.1016/j.jaap.2016.03.014

Liu Y, Zhang CJ, Zhao JC, Guo Y, Zhu P, Wang DY (2016b) Bio-based barium alginate film: preparation, flame retardancy and thermal degradation behavior Carbohyd Polym 139:106-114. https://doi.org/10.1016/j.carbpol.2015.12. 044

Liu Y, Zhao J-C, Zhang C-J, Guo Y, Cui L, Zhu P, Wang D-Y (2015b) Bio-based nickel alginate and copper alginate films with excellent flame retardancy: preparation, flammability and thermal degradation behavior RSC Adv 5:64125-64137. https://doi.org/10.1039/c5ra11048c

Liu Y, Zhao J-C, Zhang C-J, Guo Y, Zhu P, Wang D-Y (2015) Effect of manganese and cobalt ions on flame retardancy and thermal degradation of bio-based alginate films. J Mater Sci 51:1052-1065. https://doi.org/10.1007/ s10853-015-9435-9

Liu Y et al (2016) Effect of reactive time on flame retardancy and thermal degradation behavior of bio-based zinc alginate film. Polym Degrad Stab 127:20-31. https://doi.org/ 10.1016/j.polymdegradstab.2015.12.024

Liu Z, Li J, Zhao X, Li Z, Li Q (2018a) Surface coating for flame retardancy and pyrolysis behavior of polyester fabric based on calcium alginate nanocomposites. Nanomaterials (Basel) 8. https://doi.org/10.3390/nano8110875

Liu Z, Li Z, Zhao X, Zhang L, Li Q (2018b) Highly efficient flame retardant hybrid composites based on calcium alginate/nano-calcium borate. Polymers (Basel) $10 \mathrm{https} / / /$ doi. org/10.3390/polym 10060625

Luo Y, Lode A, Wu C, Chang J, Gelinsky M (2015) Alginate/nanohydroxyapatite scaffolds with designed core/ shell structures fabricated by 3D plotting and in situ mineralization for bone tissue engineering ACS Appl Mater Inter 7:6541-6549. https://doi.org/10.1021/am508469h

Ma X, Li R, Zhao X, Ji Q, Xing Y, Sunarso J, Xia Y (2017) Biopolymer composite fibres composed of calcium alginate reinforced with nanocrystalline cellulose. Compos A Appl Sci Manuf 96:155-163. https://doi.org/10.1016/j. compositesa.2017.02.021

Mokhena TC, Luyt AS (2017) Development of multifunctional nano/ultrafiltration membrane based on a chitosan thin film on alginate electrospun nanofibres. J Clean Prod 156:470-479. https://doi.org/10.1016/j.jclepro.2017.04. 073 
Mokhena TC, Luyt AS (2017b) Electrospun alginate nanofibres impregnated with silver nanoparticles: preparation, morphology and antibacterial properties Carbohyd Polym 165:304-312. https://doi.org/10.1016/j.carbpol.2017.02. 068

Mu X, Yuan B, Pan Y, Feng X, Duan L, Zong R, Hu Y (2017) A single $\alpha$-cobalt hydroxide/sodium alginate bilayer layerby-layer assembly for conferring flame retardancy to flexible polyurethane foams Mater Chem. Physics 191:52-61. https://doi.org/10.1016/j.matchemphys.2017. 01.023

Nabipour H, Wang X, Song L, Hu Y (2020) Laponite-based inorganic-organic hybrid coating to reduce fire risk of flexible polyurethane foams Appl Clay Sci 189. https://doi. org/10.1016/j.clay.2020.105525

Panda S, Rout TK, Prusty AD, Ajayan PM, Nayak S (2018) Electron transfer directed antibacterial properties of graphene oxide on metals. Adv Mater 30. https://doi.org/10. 1002/adma.201702149

Pollini M, Russo M, Licciulli A, Sannino A, Maffezzoli A (2009) Characterization of antibacterial silver coated yarns. J Mater Sci Mater Med 20:2361-2366. https://doi. org/10.1007/s10856-009-3796-Z

Rai MK, Deshmukh SD, Ingle AP, Gade AK (2012) Silver nanoparticles: the powerful nanoweapon against multidrug-resistant bacteria. J Appl Microbiol 112:841-852. https://doi.org/10.1111/j.1365-2672.2012.05253.x

Sedighi A, Montazer M (2016) Tunable shaped N-doped CuO nanoparticles on cotton fabric through processing conditions: synthesis, antibacterial behavior and mechanical properties Cellulose 23:2229-2243. https://doi.org/10. 1007/s10570-016-0892-3

Senturk Parreidt T, Muller K, Schmid M (2018) Alginate-based edible films and coatings for food packaging applications. Foods 7. https://doi.org/10.3390/foods7100170

Shao P, Xu P, Zhang L, Xue Y, Zhao X, Li Z, Li Q (2019) Nonchloride in situ preparation of nano-cuprous oxide and its effect on heat resistance and combustion properties of calcium alginate. Polymers (Basel) 11. https://doi.org/10. 3390/polym 11111760

Wang W et al (2015) Sandwichlike coating consisting of alternating montmorillonite and $\beta$-FeOOH for reducing the fire hazard of flexible polyurethane foam. ACS Sustain Chem Eng 3:3214-3223. https://doi.org/10.1021/acssuschemeng. $5 b 00805$
Wang Y et al. (2018) Spray-drying-assisted layer-by-layer assembly of alginate, 3-aminopropyltriethoxysilane, and magnesium hydroxide flame retardant and its catalytic graphitization in ethylene-vinyl acetate resin. ACS Appl Mater Inter10:10490-10500. https://doi.org/10.1021/ acsami.8b01556

Wang Y, Yang X, Peng H, Wang F, Liu X, Yang Y, Hao J (2016) Layer-by-layer assembly of multifunctional flame retardant based on brucite, 3-aminopropyltriethoxysilane, and alginate and its applications in ethylene-vinyl acetate resin. ACS Appl Mater Inter 8:9925-9935. https://doi.org/10. 1021/acsami.6b00998

Wu YP, Yang Y, Zhang ZJ, Wang ZH, Zhao YB, Sun L (2018) A facile method to prepare size-tunable silver nanoparticles and its antibacterial mechanism. Adv Powder Technol 29:407-415. https://doi.org/10.1016/j.apt.2017.11.028

Xu P, Shao P, Zhang Q, Cheng W, Li Z, Li Q (2019) A Novel Inherently Flame-Retardant Composite Based on Zinc Alginate/Nano-Cu2O. Polymers (Basel) 11. https://doi. org/10.3390/polym 11101575

$\mathrm{Xu}$ ZQ et al. (2017) Tannic acid/Fe3+/Ag nanofilm exhibiting superior photodynamic and physical antibacterial activity. ACS Appl Mater Inter 9:39657-39671. https://doi.org/10. 1021/acsami.7b10818

Zhang C-J, Liu Y, Cui L, Yan C, Zhu P (2016) Bio-based calcium alginate nonwoven fabrics: Flame retardant and thermal degradation properties. J Anal Appl Pyrol 122:13-23. https://doi.org/10.1016/j.jaap.2016.10.030

Zhang X, Shu Y, Su S, Zhu J (2018a) One-step coagulation to construct durable anti-fouling and antibacterial cellulose film exploiting $\mathrm{Ag} @ \mathrm{AgCl}$ nanoparticle- triggered photocatalytic degradation. Carbohyd Polym 181:499-505. https://doi.org/10.1016/j.carbpol.2017.10.041

Zhang X, Xia Y, Yan X, Shi M (2018) Efficient suppression of flammability in flame retardant viscose fiber through incorporating with alginate fiber. Mater Lett 215:106-109. https://doi.org/10.1016/j.matlet.2017.12.077

Zhao W, Qi Y, Wang Y, Xue Y, Xu P, Li Z, Li Q (2018) Morphology and thermal properties of calcium alginate/ reduced graphene oxide. Compos Polym (Basel) 10. https://doi.org/10.3390/polym10090990

Publisher's Note Springer Nature remains neutral with regard to jurisdictional claims in published maps and institutional affiliations. 